\title{
Potassium Nutrition Affects Leaf Growth, Anatomy, and Macroelements of Guzmania
}

\author{
Chao-Yi Lin and Der-Ming Yeh ${ }^{1,2}$ \\ Department of Horticulture, National Taiwan University, No. 1, Roosevelt \\ Road Section 4, Taipei, Taiwan, Republic of China
}

Additional index words. bromeliad, chlorophyll, mineral deficiency, water storage tissue

\begin{abstract}
Guzmania lingulata (L.) Mez. 'Cherry' plants were grown in coconut husk chips. All plants were given 8 mm nitrogen (N), 2 mm phosphorus (P), 4 mm calcium (Ca), and 1 mM magnesium $(\mathrm{Mg})$ at each irrigation with potassium $(\mathrm{K})$ concentration at $0,2,4$, or 6 mM. After 9 months, $K$ concentration did not alter the number of new leaves, and shoot and root dry weights. Increasing $K$ concentration did not affect the length but increased the width of the most recently fully expanded leaves (the sixth leaves). Plants under $0 \mathrm{~K}$ exhibited yellow spots and irregular chlorosis on old leaves being more severe at the middle of the blade and leaf tip. Numbers of leaves with yellow spots or chlorosis decreased with increasing $K$ concentration. Chlorenchyma thickness was unaffected by $K$ concentration, whereas water storage tissue and total leaf thickness increased with increasing $K$ concentration. Leaf $N$ concentration in the sixth or 10th leaf was unaffected by solution $K$ concentration. However, plants at 0 mu $K$ had higher $N$ concentration in the 14th leaf than those in sixth and 10th leaves. Leaf $P, C a$, and $M g$ concentrations decreased with increasing solution $K$ concentration. $K$ concentrations were higher in the sixth leaf than the 14th leaf in plants at 0,2 , or $4 \mathrm{~mm} \mathrm{~K}$, whereas leaf $K$ concentration was $15 \mathrm{~g} \cdot \mathrm{kg}^{-1}$ on dry weight basis in the sixth, 10th, or 14th leaves in plants treated with 6 mM K.
\end{abstract}

Differential growth and quality responses to potassium $(\mathrm{K})$ have been reported for foliage plants. Potassium deficiency is a widespread disorder on many palm species worldwide (Chase and Broschat, 1991). Under conditions of $\mathrm{K}$ deficiency, $\mathrm{K}$ from the oldest leaves is mobilized for use by the newly expanding leaves. Thus, removing potassiumdeficient leaves accelerates rate of decline in Phoenix robelenii O'Brien (Broschat, 1994). The oldest leaves are more suitable for analyzing $\mathrm{K}$ status in coconut and Canary Island date palms (Broschat, 1997).

Although bromeliads have been widely used for indoor foliage plants or landscape decoration for decades, most research on $\mathrm{K}$ or other nutrient uptake in bromeliads has been done in their habitats (Benzing, 2000; Richardson et al., 2000). Published report on nutrient supply for production is presently limited. In one report, grade of Aechmea fasciata Baker was unaffected by increasing $\mathrm{K}$ from 50 to $150 \mathrm{mg} / 10-\mathrm{cm}$ pot per month (Poole and Conover, 1976). The tropical foliage species Aglaonema commutatum Schott, however, did not respond to increased $\mathrm{K}$ from 80 to $320 \mathrm{mg} / 15-\mathrm{cm}$ pot per month (Poole and Conover, 1977). Spathiphyllum 'Sensation' initially grew normally under K-deficient conditions with healthy appearance (Yeh et al., 2000).

Received for publication 30 May 2007. Accepted for publication 29 Aug. 2007.

${ }^{1}$ Professor.

${ }^{2}$ To whom reprint requests should be addressed; e-maildmyeh@ntu.edu.tw
Irregular yellowish areas on the old leaves have been observed on Guzmania lingulata (L.) Mez. 'Cherry'. These affected plants tend to produce incurved leaves after storage. Yellow spots on old leaves have been reported as symptoms of $\mathrm{K}$ deficiency for palms (Broschat, 1997), Phalaenopsis (Wang, 2007), and Spathiphyllum 'Sensation' (Yeh et al., 2000).

No controlled studies have been conducted to characterize the specific symptoms of Guzmania K deficiency and to quantify K requirements. The objective of this study was to determine the growth, leaf anatomy, and macronutrient concentrations of Guzmania lingulata 'Cherry' under various solution $\mathrm{K}$ concentrations.

\section{Materials and Methods}

Nonflowering plants of Guzmania lingulata 'Cherry' with 10 to 13 fully expanded leaves were planted in plastic containers containing $0.9 \mathrm{~L}$ of $1-\mathrm{cm}$ diameter coconut husk chips commonly used for commercial production of bromeliad. The experiment was conducted from 30 May 2005 to 9 Mar. 2006 and all plants were grown in a 30\% shaded greenhouse with an average noontime light intensity of $390 \mu \mathrm{mol} \cdot \mathrm{m}^{-2} \cdot \mathrm{s}^{-1}$ and mean daily temperature of $25^{\circ} \mathrm{C}$. The uppermost leaf was marked for each plant for determining the number of new leaves to be produced. Nutrient solutions were made from $\mathrm{K}_{2} \mathrm{SO}_{4}$, $\mathrm{NaH}_{2} \mathrm{PO}_{4} \cdot 2 \mathrm{H}_{2} \mathrm{O}, \mathrm{NH}_{4} \mathrm{NO}_{3}, \mathrm{Ca}\left(\mathrm{NO}_{3}\right)_{2} \cdot 4 \mathrm{H}_{2} \mathrm{O}$, $\mathrm{MgSO}_{4} \cdot 7 \mathrm{H}_{2} \mathrm{O}$, and $\mathrm{CaCl}_{2} \cdot 2 \mathrm{H}_{2} \mathrm{O}$ to provide (in $\mathrm{mM}) 8$ nitrogen $(\mathrm{N}), 2$ phosphorus $(\mathrm{P})$, 4 calcium $(\mathrm{Ca}), 1$ magnesium $(\mathrm{Mg}), 2$ sodium, and 2 chloride with $\mathrm{K}$ concentration at $0,2,4$, or $6 \mathrm{~mm}$. Plants were each fertigated weekly with $0.2 \mathrm{~L}$ of nutrition solution. Sulfate concentration increased from 0 to $3 \mathrm{~mm}$ as a necessary result of applying the $\mathrm{K}$ treatments. Tap water [electrical conductivity (EC) at $0.2 \mathrm{dS} \cdot \mathrm{m}^{-1}$ ] was used to prepare all solutions. The micronutrients of the tap water was $\left(\mathrm{mg} \cdot \mathrm{L}^{-1}\right) 0.017$ iron and 0.016 zinc measured with an inductively couples argon plasma (ICP) emission spectrometer (Thermo Jarrell Ash Co., Boston, NY). At the end of experiment, the medium EC and $\mathrm{pH}$ were measured using pourthrough extracts (Wright, 1986). As $\mathrm{K}$ concentration increased from 0 to $6 \mathrm{~mm}$, the medium EC ranged from 0.53 to $0.92 \mathrm{dS} \cdot \mathrm{m}^{-1}$ as measured with a conductivity meter (SC-170; Suntex, Taipei, Taiwan), and $\mathrm{pH}$ increased from 5.7 to 6.0 as measured with a microcomputer $\mathrm{pH}$ meter (6171; Jenco Instruments, San Diego, CA).

At the end of the experiment, numbers of new leaves and leaves with yellow spots ( $\geq 1$ - to 2-mm diameter) or chlorosis were recorded in each treatment. The most recently fully developed leaf (leaf 6 from the apex) from all six plants in each treatment was sampled for measuring leaf length and width. Relative chlorophyll contents of the sixth and 15th leaves from all six plants in each treatment were measured in situ with a chlorophyll meter (SPAD-502; Minolta Camera Co., Tokyo). Three SPAD-502 readings were taken on the middle of the blade. Epidermis impressions were made on the fresh intact seventh leaves by applying a transparent glue, which covered $\approx 3 \times 3 \mathrm{~cm}^{2}$ of the abaxial surface. After drying (2 to $3 \mathrm{~min}$ ), the imprints were removed from the leaf with a clear adhesive tape and mounted on a microscope slide. Stomatal frequency and percentage of opening stomata (numbers of opening stomata/total stomata number) were determined. Samples were taken from all plants, each with 10 replications per plant. The seventh leaf was cross-sectioned to measure leaf thickness. Shoots and roots were collected and oven-dried at $70{ }^{\circ} \mathrm{C}$ for $72 \mathrm{~h}$ to determine dry weights. Relative water content of the whole leaves was calculated as [(fresh weight - dry weight $) /$ fresh weight $] \times$ $100 \%$. Samples were taken from all treatments, each with six replications. Concentrations of $\mathrm{N}$ in leaves 6 (most recently expanded leaf), 10 (middle leaf), and 14 (old leaf) from all plants in each treatment were determined with the Kjeldahl procedure and that of $\mathrm{P}, \mathrm{K}, \mathrm{Ca}$, and $\mathrm{Mg}$ were analyzed with an ICP emission spectrometer.

This experiment was arranged in a completely randomized design. Treatments were replicated six times with a single plant per replication. Linear and quadratic regression analyses were performed and presented using Sigma Plot 8.0 programming (SPSS, Chicago).

\section{Results and Discussion}

The number of new leaves and shoot and root dry weights were unaffected by $\mathrm{K}$ concentration in the nutrient solution (Table 1). Similarly, grade of Aechmea fasciata was 
unaffected by increasing $\mathrm{K}$ from 50 to 150 $\mathrm{mg} / 10 \mathrm{-cm}$ pot per month (Poole and Conover, 1976). Aglaonema commutatum did not respond to increased $\mathrm{K}$ from 80 to $320 \mathrm{mg} /$ $15-\mathrm{cm}$ pot per month (Poole and Conover, 1977).

Reducing solute $\mathrm{K}^{+}$provision may limit lateral cell expansion. The width of the most recently fully expanded leaves increased with increasing $\mathrm{K}$ concentration to $4 \mathrm{~mm}$ (Table 2). This is consistent with previous reports that $\mathrm{K}$ is known as the dominant osmoticum and contributes to cell enlargement and leaf expansion (Fricke et al., 1994; Fricke and Flowers, 1998; Shabala et al., 2000). Wang (2007) reported that Phalaenopsis produced wider leaves as $\mathrm{K}$ concentration in the nutrient solution increased.

The 0-K treatment reduced chlorophyll in the old leaves. Numbers of leaves with yellow spots and irregular chlorosis decreased with increasing $\mathrm{K}$ concentration (Table 2; Fig. 1). After treatments for 3 months, the old leaves on plants deficient of $\mathrm{K}$ began to exhibit yellow spots. Similar yellow spots as a result of K deficiency have been reported for palms (Chase and Broschat, 1991), Phalaenopsis (Wang, 2007) and Spathiphyllum 'Sensation' (Yeh et al., 2000). Symptoms of severe $\mathrm{K}$ deficiency were expressed as uneven chlorosis of old leaves being more severe at the middle of the blade and leaf tip.

Bromeliads have a unique water storage tissue to overcome drought stress. In Tillandsia ionantha Planch (Nowak and Martin, 1997), the cross-sectional area of the water storage tissue decreased rapidly and was completely exhausted after $50 \mathrm{~d}$ of drought treatment, whereas the cross-sectional area of the chlorenchyma declined by only $12 \%$. Chlorenchyma thickness was unaffected by K concentration in Guzmania, whereas water storage tissue and total leaf thickness increased with increasing $\mathrm{K}$ concentration (Table 3; Fig. 2). Because Guzmania reduced leaf water storage tissue under $\mathrm{K}$ deficiency, the K-deficient leaves may be more susceptible to severe drought stress and become incurved.

Relative water content increased with increasing $\mathrm{K}$ concentration in Guzmania (Table 3), likely the result of increased water storage tissue. Stomatal frequency on the recently fully developed leaves was unaffected by $\mathrm{K}$ concentration, whereas the percentage of opening stomata decreased with increase in $\mathrm{K}$ concentration (Table 3 ). This is

Table 1. Effects of potassium concentration on new leaf number and dry weights of Guzmania lingulata Cherry.

\begin{tabular}{lccc}
\hline $\begin{array}{l}\text { Potassium } \\
\text { concn. } \\
(\mathrm{mm})\end{array}$ & $\begin{array}{c}\text { New } \\
\text { leaf } \\
\text { number }\end{array}$ & $\begin{array}{c}\text { Shoot } \\
\text { dry wt } \\
\text { (g/plant) }\end{array}$ & $\begin{array}{c}\text { Root } \\
\text { dry wt } \\
\text { (g/plant) }\end{array}$ \\
\hline 0 & 14.7 & 6.9 & 2.0 \\
2 & 15.3 & 8.0 & 2.4 \\
4 & 15.7 & 8.7 & 2.2 \\
6 & 14.7 & 7.4 & 2.3 \\
Significance & $\mathrm{NS}$ & $\mathrm{NS}$ & $\mathrm{NS}$ \\
\hline
\end{tabular}

Nonsignificant. consistent with Arguero et al. (2006) who reported that $\mathrm{K}$ starvation increased $g_{\mathrm{S}}$ in olive trees, especially under water stress conditions. It is well documented that $\mathrm{K}$ serves a crucial function for cell osmoregulation, turgor maintenance, cell expansion, and stomatal function (Shabala, 2003).

Nitrogen concentrations in the 10th and 14th leaves were unaffected by solution $\mathrm{K}$ concentration (Fig. 3). The sixth leaves, however, had higher $\mathrm{N}$ concentration in plants under $0 \mathrm{~K}$ compared with those with 2 to $6 \mathrm{~mm} \mathrm{~K}$. Increasing absorption of $\mathrm{NH}_{4}{ }^{+}$ can displace the role of $\mathrm{K}^{+}$in osmotic function (Xu et al., 2002), and that may explain why higher leaf $\mathrm{N}$ concentration in the K-deficient Guzmania.

Leaf $\mathrm{P}$ concentration also decreased with increasing solution K concentration (Fig. 3). Baghour et al. (2001) showed that increasing $\mathrm{K}$ fertilization resulted in reduced concentrations of inorganic, organic, and total $\mathrm{P}$. Nitrogen and $\mathrm{P}$ are highly mobile, and thus $\mathrm{N}$

or $\mathrm{P}$ concentrations are lower in old leaves in $\mathrm{N}$ - or P-deficient plants (Mengel and Kirby, 1982). However, $\mathrm{N}$ and $\mathrm{P}$ concentrations are higher in the 14th leaf than the sixth leaf (Fig. 3), suggesting that Guzmania plants were not under $\mathrm{N}$ or $\mathrm{P}$ deficiency in the current experiment.

Leaf $\mathrm{K}$ concentration increased with increasing solution $\mathrm{K}$ concentration (Fig. 3). Except for the $6 \mathrm{~mm} \mathrm{~K}$ treatment, $\mathrm{K}$ concentrations were higher in the sixth leaf than the 10 th or 14th leaves. New leaves in all Guzmania plants appeared healthy throughout this experiment. These clearly demonstrate that $\mathrm{K}$ is highly mobile in Guzmania. Similar to some palms (Broschat, 1997), the old leaves were a better indicator of Guzmania $\mathrm{K}$ status than the recently developed leaves. Because old leaves are a $\mathrm{K}$ reservoir, removal of K-deficient palm leaves can result in fewer symptom-free leaves and an accelerated decline from $\mathrm{K}$ deficiency (Broschat, 1994).

Table 2. Effects of potassium concentration on leaf length and width, SPAD-502 reading, and numbers of leaves with yellow spots and chlorosis of Guzmania lingulata Cherry.

\begin{tabular}{|c|c|c|c|c|c|c|}
\hline \multirow{2}{*}{$\begin{array}{l}\text { Potassium } \\
\text { concn. (mM) }\end{array}$} & \multirow{2}{*}{$\begin{array}{c}\text { Sixth leaf } \\
\text { length }(\mathrm{cm})\end{array}$} & \multirow{2}{*}{$\begin{array}{l}\text { Sixth leaf } \\
\text { width }(\mathrm{cm})\end{array}$} & \multicolumn{2}{|c|}{ SPAD-502 reading } & \multirow{2}{*}{$\begin{array}{c}\text { Yellow spotted } \\
\text { leaf no. }\end{array}$} & \multirow{2}{*}{$\begin{array}{c}\text { Chlorotic } \\
\text { leaf no. }\end{array}$} \\
\hline & & & Sixth leaf & 15th leaf & & \\
\hline 0 & 29.2 & 3.57 & 39.5 & 26.0 & 9.3 & 4.2 \\
\hline 2 & 30.0 & 3.83 & 39.1 & 35.7 & 8.7 & 2.5 \\
\hline 4 & 31.7 & 4.13 & 38.6 & 34.7 & 8.0 & 1.3 \\
\hline 6 & 29.2 & 4.00 & 37.5 & 32.7 & 6.3 & 0.7 \\
\hline Significance & NS & $\mathrm{L}^{* *} \mathrm{Q}^{* *}$ & NS & $\mathrm{L}^{* *} \mathrm{Q}^{* *}$ & $\mathrm{~L}^{* *} \mathrm{Q} *$ & $\mathrm{Q}^{* * *}$ \\
\hline
\end{tabular}

, ${ }^{* * *, * * *}$ Nonsignificant or significant at $P \leq 0.05,0.01$, or 0.001 , respectively; $\mathrm{L}=$ linear; $\mathrm{Q}=$ quadratic.

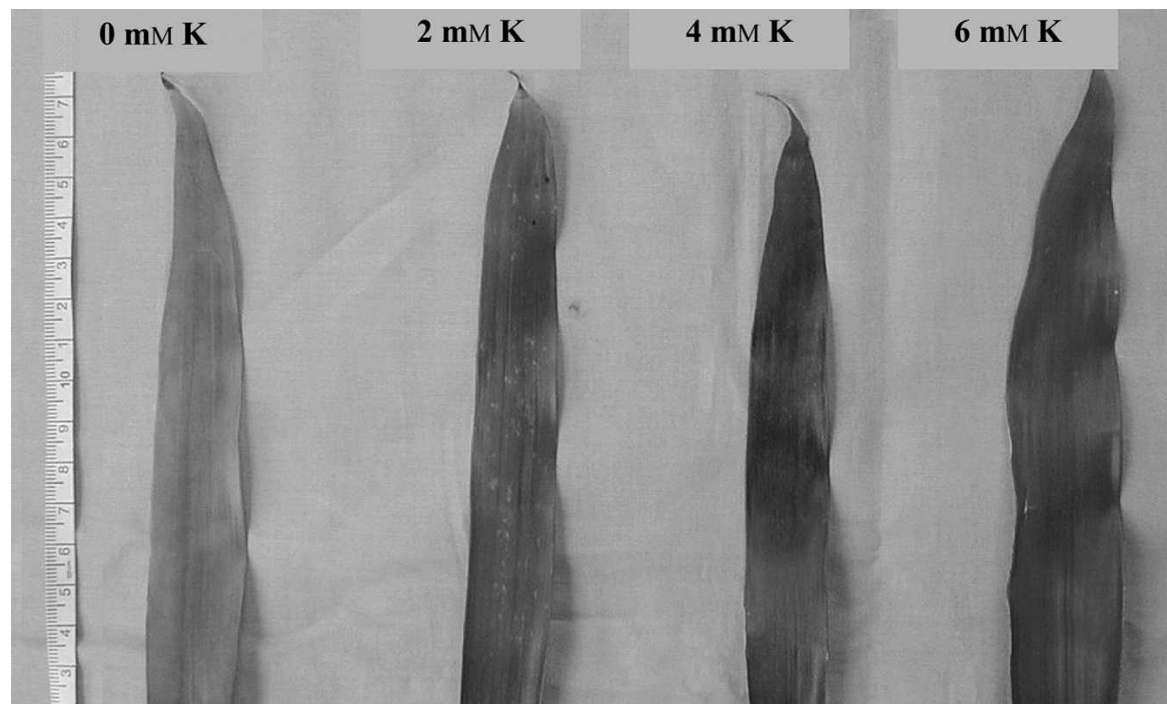

Fig. 1. Effect of potassium concentration on appearance of the 15th leaf of Guzmania lingulata 'Cherry'.

Table 3. Effects of potassium concentration on leaf tissue thickness, stomatal frequency and percentage of opening stomata, and relative water content of Guzmania lingulata Cherry.

\begin{tabular}{lccccccc}
\hline & \multicolumn{3}{c}{ Thickness $(0.01 \mathrm{~mm})$} & & Relative & & \multicolumn{2}{c}{ Stomata } \\
\cline { 2 - 3 } $\begin{array}{l}\text { Potassium } \\
\text { concn. (mM) }\end{array}$ & Chlorenchyma & $\begin{array}{c}\text { Water storage } \\
\text { tissue }\end{array}$ & Total & & $\begin{array}{c}\text { water } \\
\text { content }(\%)\end{array}$ & $\begin{array}{c}\text { No. per } \\
\mathrm{mm}^{2}\end{array}$ & $\begin{array}{c}\text { Opening } \\
(\%)\end{array}$ \\
\hline 0 & 13.0 & 7.4 & 27.2 & 80.9 & 31.0 & 30.3 \\
2 & 12.7 & 8.5 & 29.0 & 80.9 & 28.5 & 34.7 \\
4 & 12.8 & 8.5 & 29.8 & 81.4 & 31.7 & 16.5 \\
6 & 13.3 & 9.5 & 31.2 & 82.5 & 30.2 & 13.8 \\
Significance & $\mathrm{NS}$ & $\mathrm{L}^{*} \mathrm{Q}^{*}$ & $\mathrm{~L}^{* * *} \mathrm{Q}^{* * *}$ & $\mathrm{~L}^{* *} \mathrm{Q}^{* *}$ & $\mathrm{NS}$ & $\mathrm{L}^{*}$ \\
\hline
\end{tabular}

Ns,*,**,**** Nonsignificant or significant at $P \leq 0.05,0.01$, or 0.001 , respectively; $\mathrm{L}=$ linear; $\mathrm{Q}=$ quadratic. 

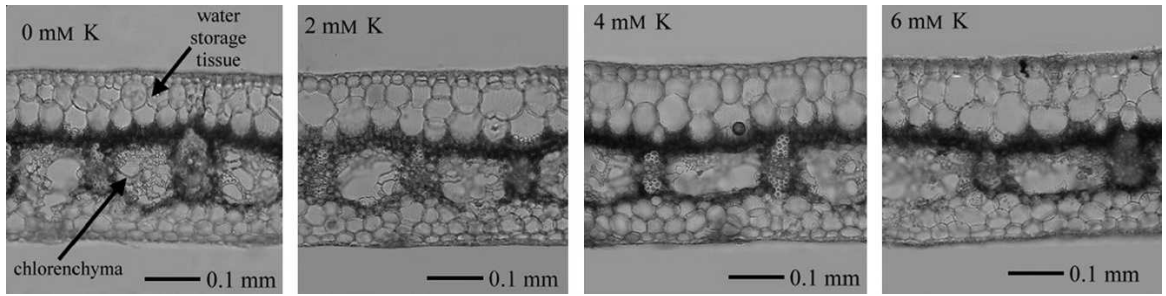

Fig. 2. Effect of potassium concentration on leaf anatomy of Guzmania lingulata 'Cherry'.

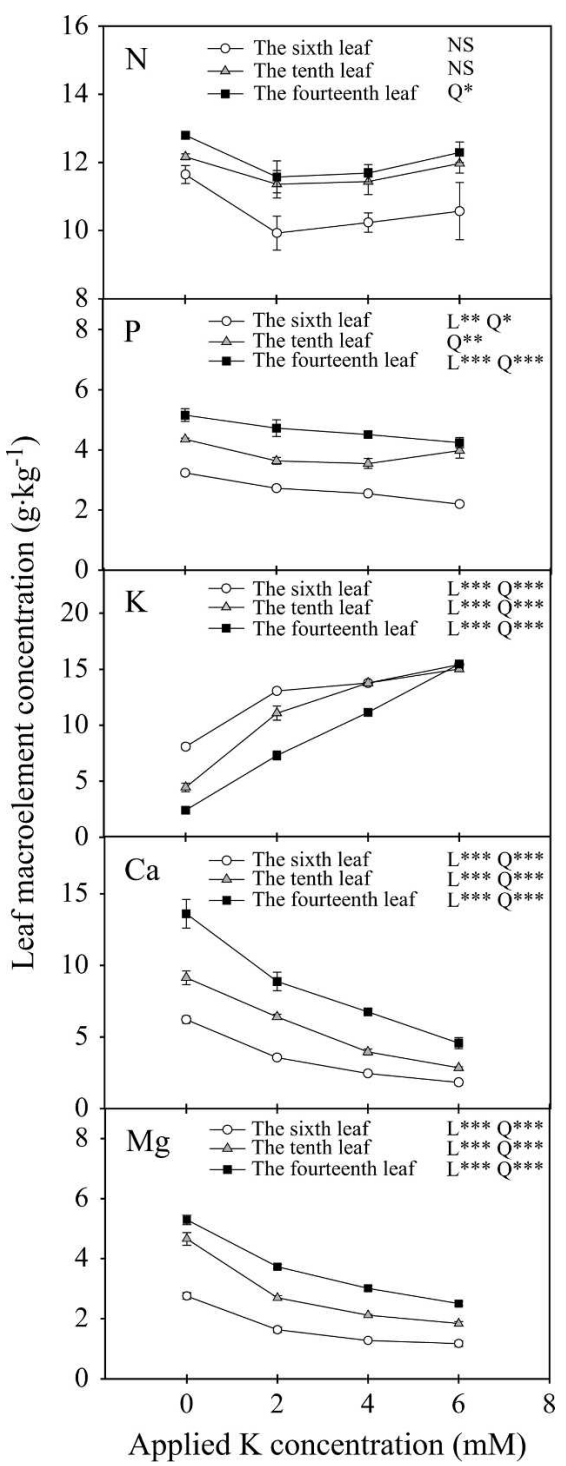

Fig. 3. Effects of potassium concentration and leaf position on leaf macroelement concentration of Guzmania lingulata 'Cherry'.

Our previous investigation on Guzmanias obtained from growers showed that leaf $\mathrm{K}$ concentration decreased gradually from leaf base $\left(14.9 \mathrm{~g} \cdot \mathrm{kg}^{-1}\right)$, middle $\left(11.0 \mathrm{~g} \cdot \mathrm{kg}^{-1}\right)$, to tip $\left(7.9 \mathrm{~g} \cdot \mathrm{kg}^{-1}\right)$ in Guzmania 'Cherry', and that coincides with the K-deficiency symptoms expressed more on the tip and middle leaf portion. Similar to other monocots, a significant higher $\mathrm{K}^{+}$concentration was also mea- sured at the growing leaf base than at the fully extended regions of corn (Mozafar, 1997) barley (Fricke and Flowers, 1998), and palm leaves (Broschat, 1997).

New leaf number and plant dry weights were not increasing at $6 \mathrm{~mm} \mathrm{~K}$; however, numbers of leaves with yellow spots and irregular chlorosis decreased at $6 \mathrm{~mm} \mathrm{~K}$ (Tables 1 and 2). In the $6 \mathrm{~mm} \mathrm{~K}$ treatment, leaf $\mathrm{K}$ concentration was $\approx 15 \mathrm{~g} \cdot \mathrm{kg}^{-1}$ on a dry weight basis in all leaves sampled (Fig. 3). These suggest that applying $6 \mathrm{~mm} \mathrm{~K}$ may be just adequate for vegetative growth of Guzmania.

As solution $\mathrm{K}$ concentration increased, leaf $\mathrm{Ca}$ and $\mathrm{Mg}$ concentrations decreased (Fig. 3). The pattern of increasing K concentration resulting in decreased leaf $\mathrm{Ca}$ and $\mathrm{Mg}$ concentrations is well documented (Mengel and Kirby, 1982; Sabreen and Saiga, 2004). $\mathrm{Ca}$ is relatively immobile in plant tissues and $\mathrm{Mg}$ is probably immobile in some plant species (Fricke et al., 1995). Thus, the 14th leaves had higher $\mathrm{Ca}$ and $\mathrm{Mg}$ concentrations than the 10th or the most recently developed leaf (Fig. 3).

\section{Conclusions}

Plant dry weight of Guzmania was unaffected under K-deficient conditions. The $0 \mathrm{~K}$ treated plants exhibited yellow spots and patches of chlorosis in old leaves that had 2 to $8 \mathrm{~g} \cdot \mathrm{kg}^{-1} \mathrm{~K}$ on a dry weight basis. Applying $6 \mathrm{~mm} \mathrm{~K}$ increased leaf width, thickness, and water content and reduced number of leaves with yellow spots or chlorosis. Recently developed leaves were appropriate for determining $\mathrm{N}, \mathrm{P}, \mathrm{Ca}$, and $\mathrm{Mg}$ concentrations, but older leaves are more suitable for analyzing the K status in Guzmania. Leaves of healthy Guzmania plants may contain $15 \mathrm{~g} \cdot \mathrm{kg}^{-1}$ or higher $\mathrm{K}$ on a dry weight basis.

\section{Literature Cited}

Arguero, O., D. Barranco, and M. Benlloch. 2006 Potassium starvation increases stomatal conductance in olive trees. HortScience 41:433436 .

Baghour, M., E. Sanchez, J.M. Ruiz, and L. Romero. 2001. Metabolism and efficiency of phosphorus utilization during senescence in pepper plants: Response to nitrogenous and potassium fertilization. J. Plant Nutr. 24:1731-1743.

Benzing, D.H. 2000. Bromeliaceae: Profile of an adaptive radiation. Cambridge University Press, Cambridge, UK.
Broschat, T.K. 1994. Removing potassiumdeficient leaves accelerates rate of decline in Phoenix roebelenii O'Brien. HortScience 29: 823.

Broschat, T.K. 1997. Nutrient distribution, dynamics, and sampling in coconut and canary island date palms. J. Amer. Soc. Hort. Sci. 122:884 890.

Chase, A.R. and T.K. Broschat. 1991. Diseases and disorders of ornamentals palms. Amer. Phytopathol. Soc. Press, St. Paul, MN.

Fricke, W. and T.J. Flowers. 1998. Control of leaf cell elongation in barley. Generation rates of osmotic pressure and turgor, and growth-associated water potential gradients. Planta 206:5365.

Fricke, W., P.S. Hinde, R.A. Leigh, and A.D. Tomos. 1995. Vacuolar solutes in the upper epidermis of barley leaves. Planta 196:40 49

Fricke, W., R.A. Leigh, and A.D. Tomos. 1994 Concentrations of inorganic and organic solutes in extracts from individual epidermal, mesophyll and bundle-sheath cells of barley leaves. Planta 192:310-316.

Mengel, K. and E.A. Kirby. 1982. Principles of plant nutrition. 3rd ed. Intl. Potash Inst., Bern, Switzerland

Mozafar, A. 1997. Distribution of nutrient elements along the maize leaf: Alteration by iron deficiency. J. Plant Nutr. 20:999-1005.

Nowak, E.J. and C.E. Martin. 1997. Physiological and anatomical responses to water deficits in the CAM epiphyte Tillandsia ionantha (Bromeliaceae). Intl. J. Plant Sci. 158:818 826.

Poole, R.T. and C.A. Conover. 1976. Nitrogen, phosphorus and potassium fertilization of bromeliad, Aechmea fasciata Baker. HortScience 11:585-586

Poole, R.T. and C.A. Conover. 1977. Nitrogen and potassium fertilization on Aglaonema commutatum Schott cvs. Fransher and Pseudobrateatum. HortScience 12:570-571.

Richardson, B.A., M.J. Richardson, F.N. Scatena, and W.H. McDowell. 2000. Effects of nutrient availability and other elevational changes on bromeliad populations and their invertebrate communities in a humid tropical forest in Puerto Rico. J. Trop. Ecol. 16:167-188.

Sabreen, S. and S. Saiga. 2004. Potassium level suitable for screening high magnesium containing grass seedlings under solution culture. J. Plant Nutr. 27:1015-1027.

Shabala, S. 2003. Regulation of potassium transport in leaves: From molecular to tissue level. Ann. Bot. (Lond.) 92:627-634.

Shabala, S., O. Babourina, and I. Newman. 2000. Ion-specific mechanisms of osmoregulation in bean mesophyll cell. J. Expt. Bot. 51:12431253.

Wang, Y.T. 2007. Potassium nutrition affects growth and flowering of Phalaenopsis grown in a bark mix or sphagnum moss substrate. HortScience . (in press).

Wright, R.D. 1986. The pour-through nutrient extraction procedure. HortScience 21:227229.

Xu, G., S. Wolf, and U. Kafkafi. 2002. Ammonium on potassium interaction in sweet pepper. J. Plant Nutr. 25:719-734.

Yeh, D.M., L. Lin, and C.J. Wright. 2000 Effects of mineral nutrient deficiencies on leaf development, visual symptoms and shoot-root ratio of Spathiphyllum. Scientia Hort. 86:223-233. 